\title{
Digitizing and Interpreting the World Map Drawn by Kashgarli Mahmud: Constructing Information Using Evidence Based Political Literacy*
}

\author{
Zekeriya Fatih İNEÇ1 \\ Erzincan Binali Yıldırım University, Erzincan \\ TURKEY
}

\author{
Erdal AKPINAR ${ }^{2}$ \\ Erzincan Binali Yıldırım University, Erzincan \\ TURKEY
}

\begin{abstract}
*A portion of this research was presented in 2. International Congress on Geographical Education (ICGE-2019), 3-5 October 2019, Eskişehir-Turkey.

${ }^{1}$ Corresponding author: Assist. Prof. Dr.. Erzincan Binali Yildirim University, Faculty of Education, Department of Preschool Education, Yalnizbag Campus, Erzincan, TURKEY. fatihinec [at] erzincan.edu.tr. ORCID: 0000-0002-2391-605X

2 Prof. Dr. Erzincan Binali Yildirim University, Faculty of Education, Department of Preschool Education, Yalnizbag Campus, Erzincan, TURKEY. eakpinar [at] erzincan.edu.tr. ORCID: 0000-0002-5281-9785
\end{abstract}

\begin{abstract}
In this study, a world map featured in Divan-1 Lugati't-Türk and drawn by Kashgarli Mahmud was made interactive through the use of Seyyah, a geographic information system (GIS) application developed in response to ADDIE, an instructional design teaching model. The geographical symbols and notes on the world map drawn by Kashgarli Mahmud were transferred to Seyyah's database so evidence-based learning could occur. The aim of the research is to evaluate the process of transforming the information obtained by the Social Studies teacher candidates with evidence into a jointly structured knowledge with the political literacy skill. The study is a qualitative action research project using a technical, scientific and collaborative approach. In this context, descriptive analysis was used to interpret the political literacy information which was interpreted and organized by Social Science teacher candidates into Seyyah's database. A standardized open-ended interview was conducted with the teacher candidates to detect the relationship between the use of Seyyah with evidence-based learning, political literacy and culture, the common structuring process and general status of information. Data from ten Social Science teacher candidates was analyzed by content analysis. The Social Science teacher candidates in the study were determined by the maximum diversity method which is a purposeful sampling method. According to the findings from Seyyah's database, Social Studies teacher candidates organized the political literacy information from the world map under four elements: cities; countries; regions and physical geography elements. There were three different categories of political knowledge in other geographical signs and nations themes. Findings obtained from the opinions of candidates show that Seyyah requires the use of high-level thinking skills in evidence-based learning to jointly structure political literacy information in a database, and present and evaluate Turkish culture in a different form.
\end{abstract}

\section{Keywords}

Evidence-Based Learning, Political Literacy, Geographical Information Systems (GIS), Culture, Social Studies Education

To cite this article: İneç, Z. F; Akpınar, E.(2020). Digitizing and Interpreting the World Map Drawn by Kashgarli Mahmud: Constructing Information Using Evidence Based Political Literacy. Review of International Geographical Education (RIGEO), 10(3), 301-327.Retrieved from http://www.rigeo.org/vol10no3/Number3Summer/RIGEO-V10-N3-3.pdf. doi: 10.33403rigeo.641521 
Divan-1 Lugati't-Turk is the first dictionary of the Turkish language, written by Kashgarli Mahmud during the Karahanli X1 period in the second half of the century. (Ercilasun \& Akkoyunlu, 2018, p.17). The author of the dictionary, Kashgarli (Kashgar) Mahmud, belongs to the Hakanlı Turks Dynasty; his real name is Mahmud bin Hüseyin bin Muhammed. Kashgar Mahmud is regarded as the founder of culture and linguistics (Yıldırım, 2008, p.107), he is also known as the first Turkish linguist (Ercilasun, 2008, p.93), lexicographer (Eraslan, 2008, p.83), etymologist (Canpolat, 2008, p.85) and cartographer (Sarıcaoğlu, 2008, p.121). Therefore, the dictionary, Divan-1 Lugati't-Turk, holds great importance to the Turkish language. (Atalay, 2018, p.8). The world map in Divan-ı Lugati't-Türk led to Kashgar Mahmud being accepted as the first Turkish cartographer. On the map, expressions are encountered such as, "All of the Turkish provinces, from the Greek country to China, are five thousand in length, eight thousand leaves. All this to be well-known and shown as a circle in the form of the earth" (Aslan, 1999). The world map in Divan-1 Lugati't-Turk was drawn to show where the Turks lived at that time. Along with the four main directions on the map, there are various physical geographical elements. Although there are some mistakes on the map, its political geographical information is largely accurate, especially for the countries and places in the east. It is quite remarkable that the world map included Japan. Indeed, the oldest known map of Japan was drawn by a Japanese cartographer in XIV Century which is about three centuries after Kashgar Mahmud wrote Divan-ı Lugati't-Turk (Aslan, 1999).

Kashgarli Mahmud drew the map to indicate the shape of the world as being round. Idrisi's Arab World Map is similar to that of Kashgar Mahmud, however, Kashgar Mahmud wrote Divan-ı Lugati't-Türk before İdrisi (Yaylagül, 2009). The world map contains a lot of information about the X1 period; therefore, it is very valuable in terms of understanding both Turkish and world history and culture. For this reason, the world map in Divan-1 Lugati't-Turk was included in the World Memory Culture by UNESCO on 24-27 October 2017.

The current research is born from the idea that the world map, drawn by Kashgar Mahmud, can be used to provide students with two basic skills (using evidence and political literacy) in a Social Studies course. As a result, it was planned to digitize the world map using Seyyah, a geographical information system application. Seyyah was developed according to the instructional design model ADDIE: Analyze; Design; Develop; Implement; Evaluate; and the world map would be presented to Social Studies teacher candidates in an interactive form. To accomplish this, the geographical and political expressions on the map were transferred to Seyyah's database which allowed the prospective Social Science teachers to jointly structure information on the system (thanks to Seyyah's coordinate algorithm). ADDIE is preferred in the current research because the model guides complex teaching processes and is interactive (Branch, 2016, p.14-17). Furthermore, Seyyah's infrastructure is based on Geographic Information Systems (GIS), which collect, store, query, analyze, present and exchange geographic information (Ministry of Environment and Forestry [MEF], 2008).

The digitized world map drawn by Kashgar Mahmud was integrated into Seyyah, and used as the primary form of evidence in the study. Evidence is defined as data obtained by querying documents (Dilek, 2007, p.25). Learning by using evidence is 
described as a type of learning that allows a related time-period and its people to be questioned and empathized with through analyzing various historical documents in response to questions such as Why? What for? and How? (Dilek, 2007, p.72).

The map of Kashgar Mahmud is first-hand evidence and the reason why the ability to use evidence is preferred for the current study is because such a skill is not sufficiently supported sufficiently in textbooks, However, students can establish the relationships of cause and effect through the use of evidence in lessons, and can therefore develop reasoning skills and gain an understanding about different perspectives (Doğan, 2009; Kabapınar, 2014, p.252).

The ability to use evidence, which is the main theme of this study, is one of the basic skills of the Social Studies Curriculum (Kabapınar, 2014, p.257; Ministry of National Education [MoNE], 2018, p.9). Using evidence in Social Science is also in accordance with the basic philosophy of the program (Kabapınar, 2019, p.31). However, when the relevant literature is examined, it is seen that there is no simple definition for using evidence. Learning by using evidence occurs in a complex process and requires the use of instruments and evidence such as documents, pictures and photographs. In this context, it is seen that using evidence is a skillusing and skill-developing strategy in itself. Students can first access the evidence by doing research, primarily to structure meaningful information in the cognitive learning process; then they can classify the evidence, which is the source of information, by perceiving time and chronology. Thus, students can evaluate events and facts from multiple perspectives and objectively structure information in their minds.

In Social Studies courses, students reach objective information by using copies of information and documents (Doğan, 2008). In the current study, Social Studies teacher candidates are supported to learn by using evidence through exposure to a digital culture environment.

In the study, along with the use of evidence, Social Studies teacher candidates also needed to use their political literacy skills to make sense of the political elements on the world map and then input the data accurately into Seyyah (Tarhan, 2015). The main reasons for political literacy skills being preferred in the study are: political literacy skills are reflected to the Social Studies curriculum (Görmez, 2018); political knowledge is prominent in citizenship education (Kuş, 2013, p.212); and the world map drawn by Kashgar Mahmud contains a large quantity of political elements and information. The prospective Social Science teachers transformed information from the world map drawn by Kashgar Mahmud into Seyyah by using their political literacy skills in conjunction with evidence about political information from the given time. When evaluated within this framework, political literacy explains the state of having various abilities to apply knowledge and understanding by creating a treasure of political knowledge in the process of making decisions about society (University of Birmingham [UoB], 2002).

In the current study, the world map drawn by Kashgar Mahmud and the political elements on the map are presented to the prospective Social Studies teachers as evidence. Using this evidence, candidates restructure the political elements on the map with their own political information. In a simpler expression, Social Science 
teacher candidates make sense of the world map drawn by Kashgar Mahmud by combining their interpretation of the map with their existing political knowledge and understanding. Therefore, the political literacy skills of the Social Science teacher candidates are developed because then they have to transform an on-paper hand-drawn world map in to an interactive form using Seyyah.

In this study, answers to the following questions were sought:

Question 1: What are the opinions of the Social Studies teacher candidates about the political elements evident on the world map drawn by Kashgar Mahmud?

To find the answer to this question, according to the categories of political elements from the world map drawn by Kashgar Mahmud, the following questions were posed to Social Studies teacher candidates:

- What are their views about cities?

- What are their views about countries?

- What are their views about physical elements (seas, rivers, steppes, mountains, dunes, hot and cold areas)?

- What are their views about realms?

- What are their views about other geographical signs?

- What are their views about nations?

Question 2: What are the opinions of the Social Studies teacher candidates about Seyyah?

In order to find an answer to this question and evaluate Seyyah in many ways, the following questions were directed to Social Studies teacher candidates:

- What are their views about learning with evidence?

- What are their views about political literacy?

- What are their views about the process of jointly constructing information?

- What are their opinions about the presentation of Turkish culture in a different form?

- What are their general opinions about the study?

The current study is important because the world map, drawn by Kashgar Mahmud in Divan-ı Lugat-it Türk has not been researched much, meaning its contribution to world heritage is relatively limited (Yıldırım, 2008); the world map is rich in terms of the political information and data it contains (Gül, 2008); and the use of Seyyah is associated with two special purposes of the Social Studies Curriculum.

\section{Material \& Methods}

\section{Material}

In the research, Seyyah, which is a GIS application and an instructional tool was developed in response to the ADDIE instructional design model (İneç, 2012; İneç \& 
Akpınar, 2012). Seyyah, developed for academic purposes in Turkey. It is a private web mapping tool with multiple functions. It has its own coordinate algorithm. This algorithm is based on the $\mathrm{x}, \mathrm{y}$ coordinate order. Seyyah was manufactured in 2010 with web 2.0 tools. Some improvements have been made in Seyyah for this study; the system has reached the 1.1 version level. While the system is mostly stable, it needs web 3.0 technologies at some points. Seyyah digitizes geographical data and stores it in the database. Geographical data can easily be recalled during the query. Seyyah also allows the data to be jointly constructed by users. It minimizes the size of the resulting data by optimizing it. In this study, first of all, the world map drawn by Kashgar Mahmud is available and it has also been digitized and integrated in to Seyyah (Figure 1). Adobe Fireworks CS6 program was used in this process. While remaining true to the core of the map, some visual effects have been applied to add a realistic look to the map. The geographical data on the world map drawn by Kashgar Mahmud has been transferred to Seyyah's database and matched with the coordinate system. In this mapping process, geographical signs have been transformed into an interactive form thanks to Seyyah's dynamic database for jointly constructing the information. Briefly, the world map drawn by Kashgar Mahmud became dynamic and interactive through the use of GIS technology. Seyyah can be reached at http://www.precoder.net domain.

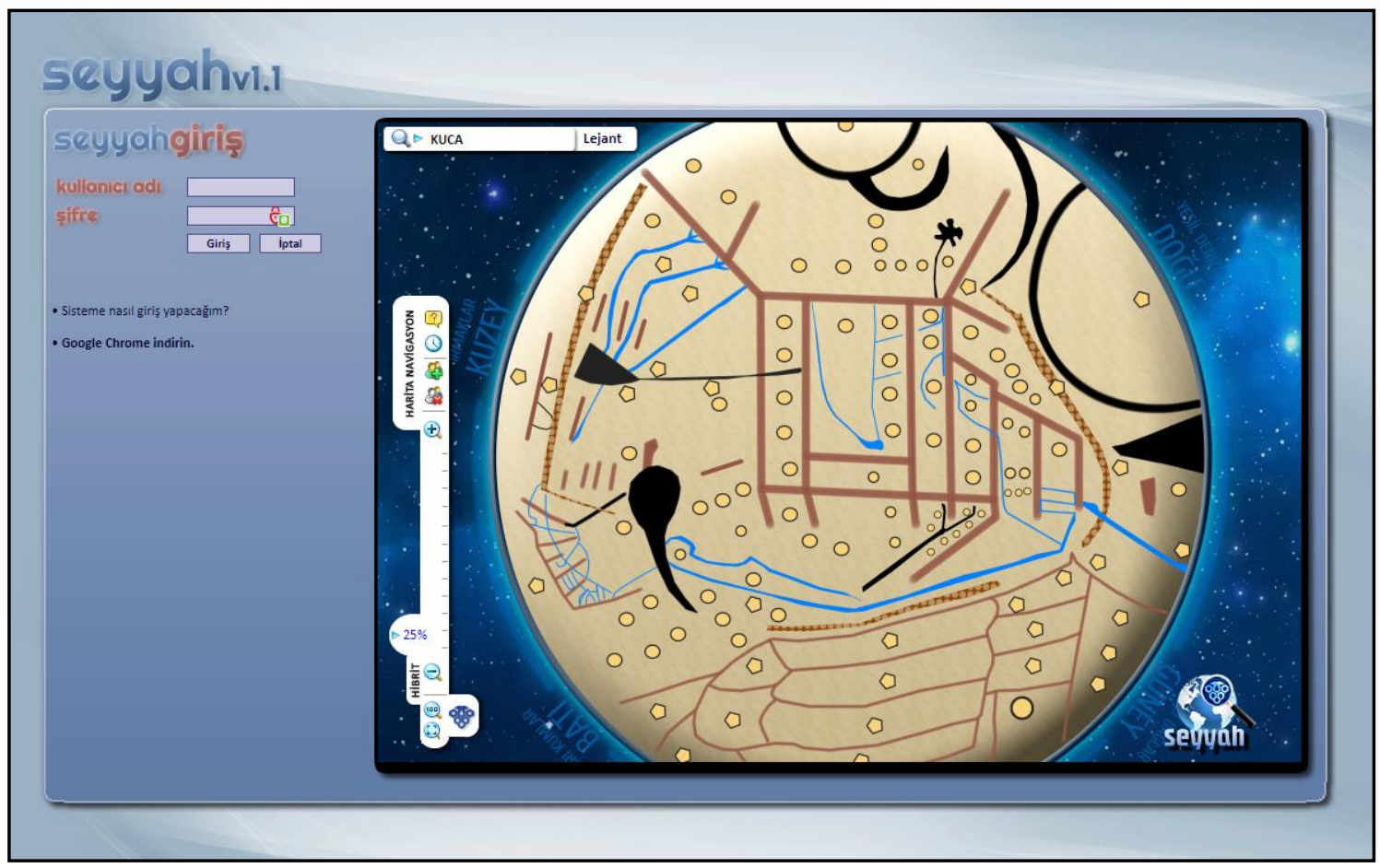

Figure 1. Seyyah v1.1 screenshot

\section{Research Process}

The research was carried out in the Political Geography course in the faculty of education at one of the state universities with the participation of third grade Social Studies teacher candidates studying in the fall semester of 2018 - 2019 academic year. Before the activity, usernames and passwords were defined to make sure the teacher candidates could access Seyyah. The study lasted ten weeks with activities 
occurring in and outside of class time. The first time the Social Science teacher candidates accessed Seyyah was during a two-hour lesson in a computer laboratory at the university. Subsequent access was made to Seyyah in non-class time and via non-laboratory devices (personal or anonymous computers, tablets and phablets).

\section{Usage of Seyyah}

Seyyah is an online GIS application that broadcasts on http://www.precoder.net domain name. Access to Seyyah takes place with usernames and passwords. People who are not authorized to use Seyyah can enter it for viewing purposes only.

After the Social Science teacher candidates logged in to Seyyah with their user names and passwords, they can navigate the world map with simple mouse movements and view the political and geographical information stored in Seyyah's database. The teacher candidates can click on these information signs to open a small data window and enter information. In the study, it is the intent that teacher candidates will jointly construct the information. The world map drawn by Kashgar Mahmud is used to support the ability to use evidence whereas the political information on the map is used to support the development of political literacy skills. Thus, it is planned that the political information on the world map in Seyyah will be jointly constructed by ten Social Science teacher candidates who are participating in the study. As a result, it is thought that evidence-based political information will emerge (Figure 2). Accordingly, data was entered into the political information windows. Therefore, the political information on Seyyah is the jointly constructed information from the teacher candidates.

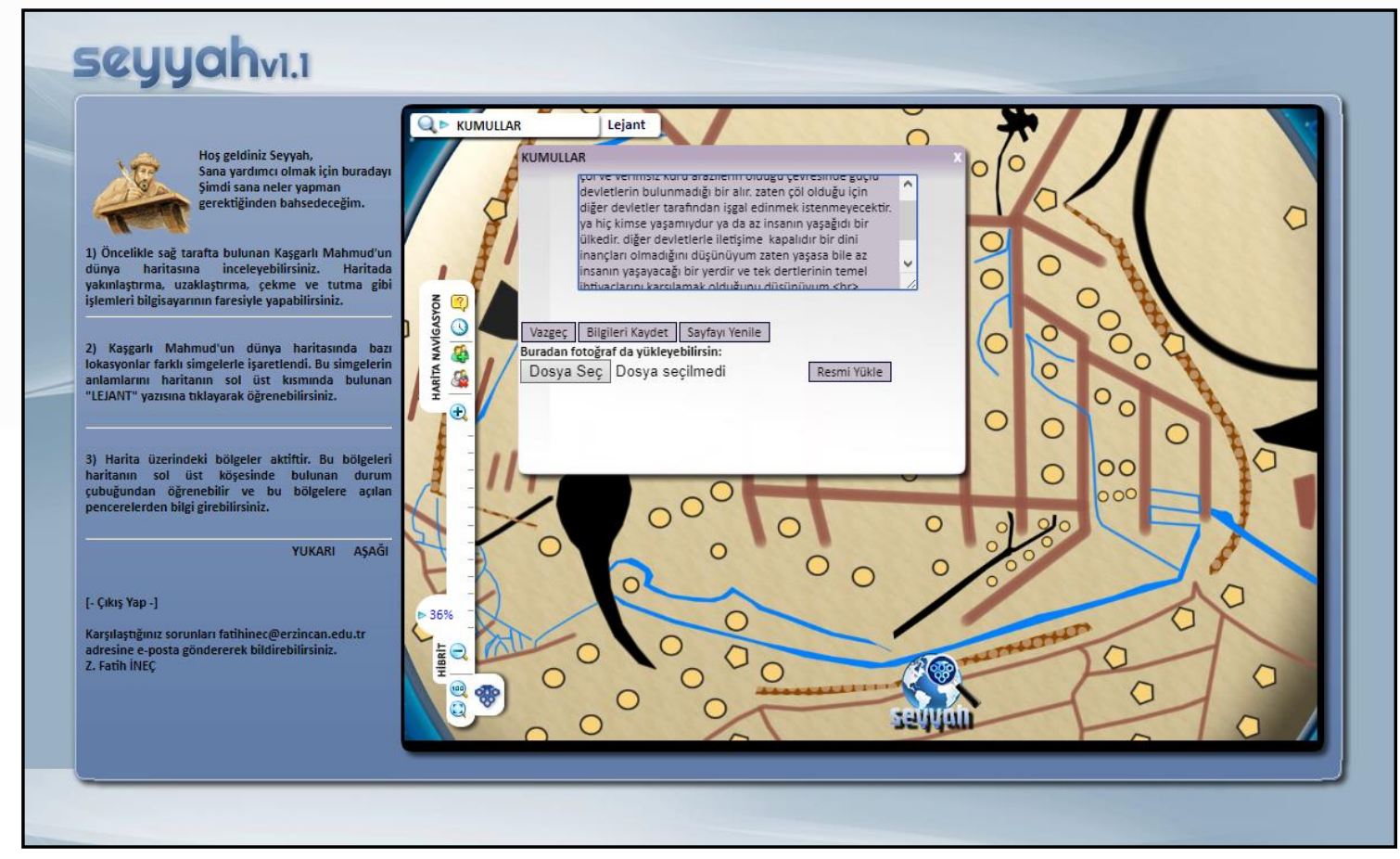

Figure 2. An evidence-based political information (dunes) jointly structured by teacher candidates 


\section{Model of the Research}

Two stages are foreseen for the research.

In the first stage, technical, scientific and collaborative action research was used to evaluate the information that was jointly constructed in Seyyah's database by Social Studies teacher candidates. In this type of research, the practitioner that masters a theoretical framework can test, implement or evaluate an application. The process creates a continuous interaction between researchers (Ylldırım \& Şimșek, 2013, p.334-343). The reason for choosing this research method is that one of the researchers dominates the pedagogical and technical theoretical framework, and the other applies a new approach as a practitioner within the course activities. Accordingly, research questions have been identified. The data that teacher candidates jointly constructed about the political elements on Seyyah were evaluated as documents, which is one of the data sources of action research. These data are structured in Seyyah's database, and these should be interpreted and described.

As a result of monitoring the findings, an action plan to monitor the situation was developed about the effective use of skills envisaged for use on Seyyah and in the joint construction of information. In the preparation of these plans, Social Studies teacher candidates' having logic problems in the initial information structuring process was effective. Therefore, a new action plan has been implemented and the problem has been resolved. Due to the interactive nature of technical, scientific and collaborative action research, the researcher enabled the practitioner to use the new action plan during implementation (Yıldırım \& Şimşek, 2013, p.334-343). In this framework, the content structured in Seyyah's database has been analyzed through descriptive analysis in order to obtain political literacy data. The reason for choosing this type of analysis is that the political data on the world map drawn by Kashgar Mahmud is structured into certain themes (Yıldırım \& Şimşek, 2013, p.256).

In the second stage, the interview method was used to collect data from the candidates in the evaluation of Seyyah, as a multifunctional teaching material. The reason for choosing this method is to measure the Social Studies teacher candidates' perceptions, reactions and experiences about the use of Seyyah (Yıldırım \& Şimșek, 2013, p.339). To accomplish this, at the end of the event, a standardized open-ended interview was held with Social Studies teacher candidates to identify Seyyah's relationship with evidence-based learning, political literacy, the information building process and our culture. Thus, researchers were provided to act objectively and to obtain systematic and in-depth information. In this context, the questions were asked to all teacher candidates in the same format in a regular order (Ylldirım \& Şimşek, 2013, p.151). In addition, the general opinions of the candidates about Seyyah were tried to be measured. A content analysis method was used to reveal the concepts and relationships that could explain the obtained data (Yıldırım \& Şimșek, 2013, p.259).

\section{Working Group}

The participant group for the current study was formed with maximum diversity sampling, which is a purposeful sampling method. The group consists of ten (10) 
students selected from among fifty-six Social Studies teacher candidates studying in the third grade in the department of Social Studies education and taking political geography lesson. The most important reason for this method to be preferred is to reach the small and diverse sample that is related to each other (Yıldırım \& Şimșek, 2013, p.136). Ten (10) Social Studies teacher candidates were determined by this sample and were then evaluated according to their overall academic grade averages and their performance in the Political Geography course. Thus, candidates with the lowest, medium and highest academic performance were studied.

\section{Data Collection Tools}

Political literacy knowledge levels of Social Studies teacher candidates were obtained through Seyyah's database. In order to descriptively analyze the collectively created information, a list of codes (categories) were created with the support of two experts from the field of Political Science, a specialist from the field of Sociology and the relevant literature (Kuş, 2013, p.207-229). This code list consists of keywords with political information.

A standardized open-ended interview proposed by Patton (1987, p.112) was conducted to determine the opinions of Social Studies teacher candidates towards the use of Seyyah. In this approach, researchers carefully determine the research questions and deliver them to more than one participant (Yıldırım \& Şimşek, 2013, p.151). In this approach, which has similar features with face-to-face meetings, participants express their thoughts freely and comfortably. In this framework, the second question and sub-questions of it have been turned into an online questionnaire to obtain objective opinions of teacher candidates. Thus, the evaluation, transfer and analysis of the views have become easier (Akbaba Altun \& Memişoğlu, 2008). The form also contains information that the research results will be used for scientific studies and will not be shared with third parties. In addition, personal data of teacher candidates were not requested in the form. After the activities on Seyyah were completed, the URL of the online questionnaire was shortened and sent to teacher candidates with a social media application. The form, which was evaluated in an average of thirty minutes, included data entry fields under each research question in which opinions will be written. The form consisted of a single web page and saved the entered data in its own database. These data were then transformed into non-attribute text for content analysis.

\section{Data Analysis}

Descriptive analysis was used in the analysis of evidence-based political qualitative information constructed in the Seyyah database by the Social Science teacher candidates. Descriptive analysis is an effective technique to reach complete information about facts and events (Büyüköztürk et al., 2013, p.22). The need to describe the data obtained in the study model and to edit and interpret the structured political information determined the use of this approach (Yildırım \& Şimşek, 2013, p.256). Kashgar Mahmud divided the political elements on his map into six categories (cities, countries, physical elements, lands, other geographical signs, nations) and the analysis of the data in Seyyah's database was carried out through these categories. 
In the analysis of qualitative data, a content analysis technique was used to determine the human behavior and nature of the Social Science teacher candidates when using Seyyah (Büyüköztürk et al., 2013, p.240). The reason for choosing this technique is that it is desired to reveal the facts about the data about Seyyah. Thus, in addition to the skills and knowledge of Social Science teacher candidate use of Seyyah, the inherent facts about the cultural and general aspects of Seyyah are also determined. In this framework, qualitative data were coded, the main subject categories were revealed and the data were arranged according to the codes and themes. Then, the findings were identified and interpreted (Yıldırım \& Şimşek, 2013, p.259-261).

In calculating the reliability of the research, four expert opinions were sought and the Miles and Huberman (1994) reliability formula was used:

Reliability = Consensus / (Consensus + Disagreement)

With the above formula, the reliability of the research was determined to be $86 \%$. This result is considered reliable for research (Miles \& Huberman, 1994).

\section{Findings}

\section{Opinions of The Social Studies Teacher Candidates About the Political Elements Evident on The World Map Drawn by Kashgar Mahmud}

Findings in which the Social Studies teacher candidates' share their opinions about the political elements on the world map drawn by Kashgar Mahmud are determined in tables below. Kashgar Mahmud reflected the political information about his period on the map with the themes of cities, countries, physical elements, lands, other geographical signs and nations.

Teacher candidates' opinions about the cities on the world map drawn by Kashgar Mahmud and based on Seyyah application. When Table 1 is analyzed, it is seen that Social Studies teacher candidates use their political literacy skills to express the cities on the map in the categories of geographical features, ethnicity, power and religion categories. Eighteen of the thirty-four cities on the map had political information jointly constructed, and sixteen not. Jointly constructed political information about cities were identified as Cend, Varang, Amc, Alexandria, Taraz, Fivefish, Canbal, City of Women, Burial Housing, Serendib, Samarkand, Özcend, Balasagun, Kashgar, Kumi Talas, Barsgan, Magrip, Alevis. The cities where information is not jointly constructuted are Kay Meskeni, Kıpçak and Oğuz Meskeni, Sikdi Muhdese City, Kishmir, Hokand, Marginan, Yarkend, Hoten, Curcan, Sancu, Ekki Okuz, Kuca, Barman, Uc, Kucngar Head, Kipchak Residence. 
Table 1

Teacher Candidates' Opinions About the Cities on The World Map Drawn by Kashgar Mahmud And Based on Seyyah Application.

\begin{tabular}{|c|c|c|c|}
\hline Category 1 & Codes & Participants & $(f)$ \\
\hline \multirow{3}{*}{1 Geographical features } & Geographical location & $\mathrm{c} 1, \mathrm{c} 2, \mathrm{c} 3, \mathrm{c} 5, \mathrm{c} 6, \mathrm{c} 7, \mathrm{c} 8, \mathrm{c} 9, \mathrm{c} 10$ & 9 \\
\hline & Geopolitical features & $\mathrm{c} 1, \mathrm{c} 2, \mathrm{c} 3, \mathrm{c} 4, \mathrm{c} 6, \mathrm{c} 7, \mathrm{c} 9$ & 7 \\
\hline & Climate & $\mathrm{c} 4, \mathrm{c7}, \mathrm{c} 8, \mathrm{c} 9$ & 4 \\
\hline \multirow{4}{*}{2 Ethnicity } & Culture & $\mathrm{c} 4, \mathrm{c} 8, \mathrm{c} 9$ & 3 \\
\hline & Ethnic (Turks) & c3, c6, c10 & 3 \\
\hline & Ethnic (Mongols) & $\mathrm{c} 4, \mathrm{c5}, \mathrm{c6}, \mathrm{c9}, \mathrm{c} 10$ & 5 \\
\hline & Ethnic (Minangs) & $\mathrm{c} 4, \mathrm{c} 8, \mathrm{c} 9$ & 3 \\
\hline \multirow{5}{*}{3 Power } & Technology & $\mathrm{c7}, \mathrm{c} 9$ & 2 \\
\hline & Social life & c8 & 1 \\
\hline & Social event & $c 5, \mathrm{c} 8$ & 2 \\
\hline & State & c4, c5, c6, c7, c9, c10 & 6 \\
\hline & Limits & c9 & 1 \\
\hline \multirow{4}{*}{4 Religion } & Islam & c7, c8 & 2 \\
\hline & Heavenly religions & c5 & 1 \\
\hline & Monotheistic religions & $\mathrm{c} 7, \mathrm{c} 9$ & 2 \\
\hline & Mazdaism & c8 & 1 \\
\hline Total & & & 10 \\
\hline
\end{tabular}

Some of the information that candidates have jointly constructed about cities is as follows:

\section{Cend City:}

"The city of Cend is today near the city of Kazalinska in Kizilorda state in Kazakhstan, was an end city on the border of Islam, on the left bank of the Seyhun River, in the Oghuz country in the past. At that time, Aral Lake was called Cend Lake. I think it's Cend Lake. It is a country surrounded by waters and streams. The eastern and western borders are surrounded by streams. We can say that its surroundings are covered with streams, agriculture is very productive and they are advanced in agricultural technology. It is a state that other states would want to seize because of its advanced level in agriculture and its surroundings covered with water. Just as Egypt reached the advanced level with the Nile, the city of Cend is also advanced with the streams around it. I believe that the surrounding area is covered with water, the agricultural lands are fertile and this will cause progress in agriculture in time. I think they have one god belief because Cend is within the borders of the current Muslim country. Most of the countries that were developed in that period already had a belief in one God. "

\section{Samarkand City:}

"Samarkand is the ancient city that served as the capital of the Timur State. When the Mongols were captured it, it was destroyed and burned by the Mongols and then, when Timur made it the capital, it became a developed important cultural center. It was established in the mountain and border area for protection."

Teacher candidates' opinions about countries on the world map drawn by Kashgar Mahmud and based on Seyyah application. When Table 2 is analyzed, it is seen that Social Studies teacher candidates use their political literacy skills to express the countries on the map under the categories of geographical characteristics, ethnicity, power and religion. Political information was jointly constructuted in eleven of the thirteen countries on the map, and not for two of the cities. The countries where political knowledge is structured are Derbend / Hazaran, 
Ineç, Z. F.; Akpinar, E. (2020). Digitizing and Interpreting the World Map Drawn by Kashgarli....

Black Country, Abyssinia, Chad, Berber Country, Sind Country, Cabarka / Jabarka, Maçin, Kantunsini, Uyghur Country, Hind Country. The countries where information is not structured are Persian Country, Kırman Country.

Table 2

Teacher Candidates' Opinions About Countries on The World Map Drawn by Kashgar Mahmud And Based on Seyyah Application

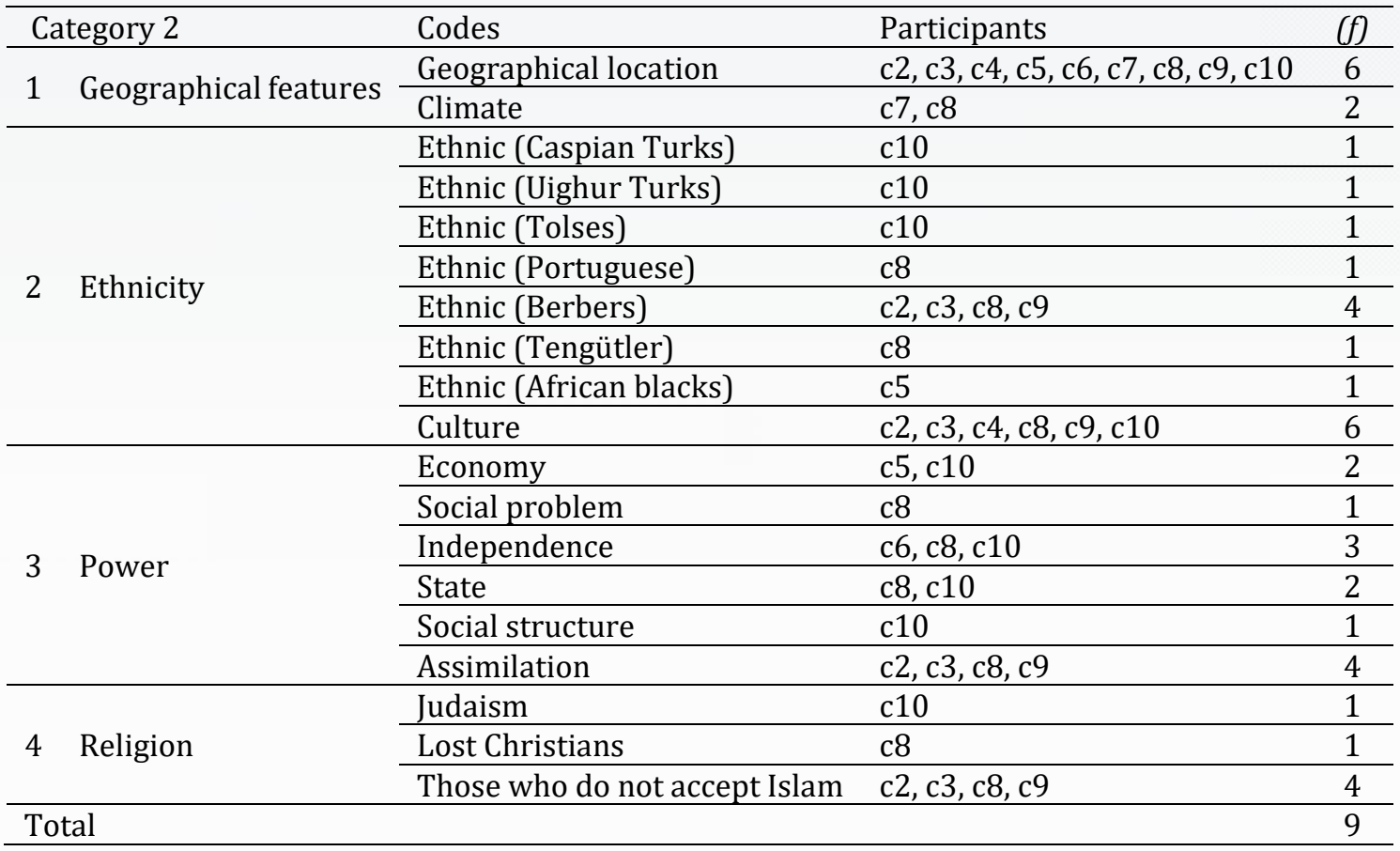

Some of the information that candidates have jointly constructed about countries are as follows:

Cabarka / Jabarka Country:

"The fact that Kashgar Mahmud included Japan in his map increases the importance of the map even more. As far as it is known, this map is the first world map in which Japan is shown. Japan is shown as an island in the east of the map and is called Cabarka. Japan, which is a sea country, has been shown independent like today's Japan."

Berber Country:

"Berbers are an interesting nation living in North Africa who are non-Arab contrary to popular belief, and speak completely in a different language, with their blond hair and blue eyes. The Berbers, who seemed to accept Islam during the Arab assimilation, continued their own customs and continued their own beliefs under the pseudonym, saint nickname. Their women have a much more active social life than Arab women, it is a country that does not leave its developed culture."

Teacher candidates' opinions about the physical elements on the world map drawn by Kashgar Mahmud and based on Seyyah application. When Table 3 is analyzed, it is seen that Social Studies teacher candidates use their political literacy skills to express the physical elements on the map under the categories of geographical features, ethnicity, power and religion. In nine of the fourteen physical elements on the map, political information is jointly constructed, and in five, it is not. 
Information that is jointly constructed about physical elements are Irtysh River, Bashkir Steppes, Basmil Steppes, Tatar Steppes, Karacuk Mountain, Sand Dunes, Seyhun, Extremely Cold Regions, Extremely hot places. Physical elements that are not jointly constructed are Abisgun Sea, Yamar River, Food Steppe, Ila River, Ceyhun River.

Table 3

Teacher Candidates' Opinions About the Physical Elements on The World Map Drawn by Kashgar Mahmud And Based on Seyyah Application.

\begin{tabular}{|c|c|c|c|c|}
\hline & Category 3 & Codes & Participants & $(f)$ \\
\hline \multirow{3}{*}{1} & \multirow{3}{*}{ Geographical features } & Geographical location & c1, c3, c6, c8, c9 & 5 \\
\hline & & Geopolitical features & $\mathrm{c5}, \mathrm{c6}, \mathrm{c} 8, \mathrm{c} 9$ & 4 \\
\hline & & Physical condition & c7 & 1 \\
\hline 2 & Ethnicity & Culture & $\mathrm{c} 1, \mathrm{c} 3$ & 2 \\
\hline 3 & Power & Politics & c8 & 1 \\
\hline 4 & Religion & Unbeliever & $\mathrm{c} 8, \mathrm{c} 9$ & 2 \\
\hline \multicolumn{2}{|c|}{ Total } & & & 7 \\
\hline
\end{tabular}

Some of the information that candidates have jointly constructed about physical elements are as follows:

Extremely cold areas:

"They are polar regions. There is no neighbor around it and the cold region is not suitable for living. There are cold deserts, lakes, mountains around it."

Sand Dunes:

"It is an area where there are no strong states around the desert and inefficient dry lands. Since it is already desert, it will not be desired to be occupied by other states. Either no one lives or is a country where few people live. It is closed to communication with other states. I think they have no religious beliefs, even if they already live, it is a place where few people will live and I think their only problem is to meet their basic needs. Desert locations consisting of a combination of areas where Gobi, Taklamakan and Karakum deserts are together."

Teacher candidates' opinions about the lands on the world map drawn by Kashgar Mahmud and based on Seyyah application. When Table 4 is analyzed, it is seen that Social Studies teacher candidates use their political literacy skills to express the lands on the map under the categories of geographical characteristics, religion, ethnicity and power categories. In eleven of the twelve lands on the map, political information is jointly constructed, and in one, it is not. Information structured lands are Damascus Land, Adarbadgan Land, Khorasan, Iraq, Land of Hazaz, Land of Yemen, Land of Huzistan, Harism, Land of God and Magog, Land Covered with Bases, Taberistan Land. The Land of Idea was not jointly constructed information. 
Ineç, Z. F.; Akpinar, E. (2020). Digitizing and Interpreting the World Map Drawn by Kashgarli.....

Table 4

Teacher candidates' opinions about the lands on the world map drawn by Kashgar Mahmud and based on Seyyah application

\begin{tabular}{|c|c|c|c|c|}
\hline & Category 4 & Codes & Participants & $(f)$ \\
\hline \multirow{4}{*}{1} & \multirow{4}{*}{ Geographical features } & Climate & c8 & 1 \\
\hline & & Physical condition & c5, c9 & 2 \\
\hline & & Geographical location & $\mathrm{c} 1, \mathrm{c} 4, \mathrm{c} 5, \mathrm{c} 6, \mathrm{c} 7, \mathrm{c} 8, \mathrm{c} 9, \mathrm{c} 10$ & 8 \\
\hline & & Geopolitical location & $\mathrm{c} 8, \mathrm{c} 7, \mathrm{c} 9$ & 3 \\
\hline 2 & Religion & Islam & $\mathrm{c} 1, \mathrm{c} 2, \mathrm{c} 4, \mathrm{c} 5, \mathrm{c} 6, \mathrm{c} 7, \mathrm{c} 9, \mathrm{c} 10$ & 8 \\
\hline \multirow{3}{*}{3} & \multirow{3}{*}{ Ethnicity } & Ethnic (Turks) & $\mathrm{c} 2, \mathrm{c} 6$ & 2 \\
\hline & & Ethnic (Turks - Arabs) & $c 5, c 6$ & 2 \\
\hline & & Ethnic (Arabs - Novices) & $\mathrm{c} 1$ & 1 \\
\hline \multirow{9}{*}{4} & \multirow{9}{*}{ Power } & War & c5, 0̈6 & 2 \\
\hline & & State & $\mathrm{c5}, \mathrm{c} 9$ & 2 \\
\hline & & Dominance & $4, c 5, c 6, c 7$ & 4 \\
\hline & & Economy & c4, c5, c7, c8, c9 & 5 \\
\hline & & Sovereignty & c9 & 1 \\
\hline & & Politics & $\mathrm{c4} 4, \mathrm{c5}, \mathrm{c7}$ & 3 \\
\hline & & Migration & $\mathrm{c} 2, \mathrm{c} 6$ & 2 \\
\hline & & Social problem & $\mathrm{c} 1, \mathrm{c} 4, \mathrm{c} 5, \mathrm{c} 6, \mathrm{c} 7, \mathrm{c} 9, \mathrm{c} 10$ & 7 \\
\hline & & Change over time & $\mathrm{c} 2, \mathrm{c} 6$ & 2 \\
\hline
\end{tabular}

Some of the information that candidates have jointly constructuted about the lands are as follows:

Land of Khorasan:

"The region where Turkmen, called as unmixed Turk progeny in Turkey today, lived before they migrated to Anatolia. Turkish tribes, who migrated from Central Asia to the west, entered into fierce wars when they faced Islam had to accept Islam without being so voluntary. Khorasan is the point where Islam and Turks meet, and the migration of Turks to the west has stopped with this encounter. However, when the Turkish interpretation was brought to Islam under the leadership of Sheikh Ahmet Yesevi (and the seeds of Alevi / Bektashism were planted), after that the Turkish tribes left Khorasan and migrated to Anatolia. The driving force of the Ottoman Empire in the first period is these Turkish tribes of Khorasan origin. Currently, in many Alevi sayings and folk songs, the name Khorasan is mentioned as a reference. Do not be surprised if your grandmother said that we came from Khorasan almost a thousand years later, it may be right."

Land of Harism:

"It includes Uzbekistan and Turkmenistan. It may have been shown between two streams as it has been poured into the river of Ceyhun, and it can be between two streams because it is an important trade place. Harism is the Ottoman word. I think the Ottomans dominated this region or had commercial relations. This region, which is between two streams, may be suitable for agriculture."

Teacher candidates' opinions about the other geographical signs on the world map drawn by Kashgar Mahmud and based on Seyyah application. When Table 5 is examined, it is seen that Social Studies teacher candidates use their political literacy skills to express the other geographical signs on the map under categories of geographical features, religion and power. Political information is jointly constructed in all five 'other geographical signs' on the map. Other structured 
geographical signs are wild animals, primitive people, Adam's footprint, Zulkarneyn Great Wall, Egyptian Border.

Table 5

Teacher Candidates' Opinions About the Other Geographical Signs on The World Map Drawn by Kashgar Mahmud And Based on Seyyah Application

\begin{tabular}{|c|c|c|c|c|}
\hline & egory 5 & Codes & Participants & $(f)$ \\
\hline \multirow{3}{*}{1} & \multirow{3}{*}{ Geographical features } & Geographical location & $\mathrm{c} 1, \mathrm{c} 2, \mathrm{c} 3, \mathrm{c} 5, \mathrm{c} 6, \mathrm{c} 7, \mathrm{c} 9$ & 7 \\
\hline & & Climate & $\mathrm{c} 2, \mathrm{c} 3, \mathrm{c} 4, \mathrm{c} 5, \mathrm{c} 6, \mathrm{c} 7, \mathrm{c} 9$ & 7 \\
\hline & & Physical condition & $\mathrm{c3}, \mathrm{c5}, \mathrm{c7}, \mathrm{c} 9$ & 4 \\
\hline \multirow{2}{*}{2} & \multirow{2}{*}{ Religion } & Heavenly and non-heavenly religions & $\mathrm{c} 1, \mathrm{c} 2, \mathrm{c3}, \mathrm{c5}, \mathrm{c6}, \mathrm{c} 9$ & 6 \\
\hline & & Heavenly religions & $\mathrm{c3}, \mathrm{c} 4, \mathrm{c} 6, \mathrm{c} 8, \mathrm{c} 10$ & 5 \\
\hline \multirow{3}{*}{\multicolumn{2}{|c|}{3 Power }} & National sovereignty & c3 & 1 \\
\hline & & Social problem & c3 & 1 \\
\hline & & Politics & c3 & 1 \\
\hline \multicolumn{3}{|c|}{ Total } & & 10 \\
\hline
\end{tabular}

Some of the information that candidates have jointly constructed about other geographical signs are as follows:

Primitive People:

"A connection like this can be established, there is a hill and a primitive man on one side and wild animals on the other, that is, a primitive period is mentioned. The impact of climate on people and the shaping of life accordingly, a period when people interact with wild animals to meet their basic needs. Humans meet some needs from those wild animals, the settlement also has many effects on people, since there is a hill, they may have done some things to overcome that hill. Besides, I think they used the things they did on those animals."

Adam's Footprint:

"Today, the footprint of Adam on the Hill of Adam in Sri Lanka is considered sacred by Muslims, Buddhists and Christians. When we examine the map, it is similar to the maps drawn today."

Teacher candidates' opinions about nations on the world map drawn by Kashgar Mahmud and based on Seyyah application. When Table 6 is analyzed, it is seen that Social Studies teacher candidates use their political literacy skills to express the nations on the map under the categories of geographical characteristics, ethnicity and power. In four of the five nations on the map, political information is jointly constructed, and in one, it is not. Information structured nations are Oghuz, Russian, Pechenegs and Bulgarians. Nations where information was not jointly constructed is Turkey. 
Ineç, Z. F.; Akpinar, E. (2020). Digitizing and Interpreting the World Map Drawn by Kashgarli.....

Table 6

Teacher candidates' opinions about nations on the world map drawn by Kashgar Mahmud and based on Seyyah application

\begin{tabular}{lllll}
\hline \multicolumn{2}{l}{ Category 6 } & Codes & Participants & $(f)$ \\
\hline \multirow{2}{*}{1} & \multirow{2}{*}{ Geographical features } & Geographical location & c4, c5 & 2 \\
\cline { 2 - 4 } & Geopolitical features & c7, c9 & 2 \\
\hline \multirow{3}{*}{2} & Ethnicity & Ethnic (Turks) & c7 & 1 \\
\cline { 2 - 4 } & Ethnic (Russians) & c7, c9 & 2 \\
\cline { 2 - 4 } & Ethnic (Pechenegs) & c3, c8 & 2 \\
\cline { 2 - 4 } & Ethnic (Bulgarians) & c4, c5 & 2 \\
\hline \multirow{3}{*}{3 Power } & State & c7, c9 & 5 \\
\cline { 2 - 4 } & Migration & c3, c4, c5, c7, c8 & 2 \\
\cline { 2 - 4 } & Politics & c7, c9 & 6 \\
\hline Total & & & \\
\hline
\end{tabular}

Some of the information that candidates have structured jointly about nations are as follows:

Pechenegs:

"After the end of the Göktürk State, the Pechenegs or the Beechens migrated from their homeland, West Siberia, from the region between the Ural Mountains and the Yenisei River, to the Koban Region, where they settled deeply and hosted themselves."

Oghuz:

"Uzs (Oghuzs), the most rooted and crowded tribe of Turkish History, came into conflict with other Turkish tribes with the fall of Göktürk Union, as a result of the struggles with the Turkish tribes in Central Asia, they migrated to the West and first reached the Caspian geography and then to the North Black Sea and carried Turkish traces to Eastern Europe. Thus, it made important contributions to the acquisition of Anatolia. "

\section{Opinions of The Social Studies Teacher Candidates About Seyyah}

Teacher candidates' opinions about evidence-based learning using Seyyah. When Table 7 is analyzed, it is seen that Social Studies teacher candidates express their views about evidence-based learning using Seyyah under four (4) different codes.

Table 7

Teacher Candidates' Opinions About Evidence-Based Learning Using Seyyah

\begin{tabular}{lllc}
\hline \multicolumn{2}{l}{ Codes } & Participants & $(f)$ \\
\hline 1 & It allows information to be compared. & $\mathrm{c} 1, \mathrm{c} 4, \mathrm{c5}, \mathrm{c6}, \mathrm{c7}, \mathrm{c} 10$ & 6 \\
\hline 2 & It develops higher-order thinking skills. & $\mathrm{c} 2, \mathrm{c} 8$ & 2 \\
\hline 3 & It conveys to objective information. & $\mathrm{c} 9$ & 1 \\
\hline 4 & It brings new information. & $\mathrm{c} 3$ & 1 \\
\hline Total & & 10 \\
\hline
\end{tabular}

Some of the statements of the Social Studies teacher candidates regarding the evidence-based learning with Seyyah are as follows:

Student 5 (It enables comparison of information):

"Thanks to Seyyah, we both research and gather information, and we have the chance to evaluate our own information with the information collected." 
Student 7 (It enables comparison of information):

"I think we always use evidence-based learning when working with Seyyah because we have always worked on our old knowledge."

A large number of candidates $(n=6,60 \%)$ mentioned that they had the opportunity to compare their information on Seyyah with other candidates. This may be related to Seyyah 's interactive function about common information.

Student 8 (It improves higher-order thinking):

"It is used to help students acquire critical thinking skills, think and process information from previous learning."

Some of the candidates $(n=2,20 \%)$ stated that they could improve their thinking skills while using their skills on Seyyah. This may mean that Seyyah developed the higher-order thinking skills while giving them the opportunity to use basic skills.

Student 9 (It conveys to objective information):

"Evidence-based learning is scientific knowledge, this knowledge has results from accessing with evidence, so that knowledge on Seyyah is objective information."

The candidate declared that Seyyah brought objective information. This may be related to the collective process of jointly constructing information in Seyyah through evidence-based learning.

Teacher candidates' opinions about political literacy when using Seyyah. When Table 8 is analyzed, it is seen that Social Studies teacher candidates express their views about the development of political literacy skills when using Seyyah under four (4) different codes.

Table 8

Teacher Candidates' Opinions About Political Literacy When Using Seyyah

\begin{tabular}{|c|c|c|c|}
\hline \multicolumn{2}{|c|}{ Codes } & \multirow{2}{*}{$\begin{array}{l}\text { Participants } \\
\mathrm{c} 1, \mathrm{c} 3, \mathrm{c} 6, \mathrm{c} 7, \mathrm{c} 9, \mathrm{c} 10\end{array}$} & \multirow{2}{*}{$\frac{(f)}{6}$} \\
\hline 1 & $\begin{array}{l}\text { It makes it possible to associate existing information with } \\
\text { political knowledge. }\end{array}$ & & \\
\hline 2 & It enables the development of different skills. & $\mathrm{c} 4, \mathrm{c} 5$ & 2 \\
\hline 3 & It arouses curiosity and leads to research. & $\mathrm{c} 2$ & 1 \\
\hline 4 & It does not reflect political literacy. & c8 & 1 \\
\hline \multicolumn{2}{|c|}{ Total } & & 10 \\
\hline
\end{tabular}

Some of the statements of the Social Studies teacher candidates regarding the development of political literacy skills when using Seyyah are as follows:

Student 6 (It makes it possible to associate existing information with political knowledge):

"I was impressed by learning about the political literacy and culture of that period by researching its social structure and comparing it with the present on Seyyah. It was very nice to evaluate the social structure of the past. It was like brainstorming. "

Student 7 (It makes it possible to associate existing information with political 
knowledge):

"Thanks to Seyyah, I learned information about the history of the places on the map, had information about countries' lifestyle, management styles, climate and which agricultural products they deal with, it allowed me to compare it with today"

A large number of candidates $(n=6,60 \%)$ stated that they could associate their current knowledge with the political information on Seyyah. This may mean that Seyyah has improved political literacy skills.

Student 8 (It does not reflect political literacy):

"To me, Seyyah does not exactly reflect political literacy."

Candidate stated that the use of Seyyah did not reflect the development of political literacy skills. However, the use of Seyyah reflects the skill of jointly constructing political knowledge with other Social Science teacher candidates. Therefore, the candidate may have criticized his other friends.

Teacher candidates' opinions about the process of jointly constructing information with Seyyah. When Table 9 is analyzed, it is seen that Social Studies teacher candidates express their views about the process of jointly constructing information with Seyyah under four (4) different codes.

Table 9

Teacher candidates' opinions about the process of jointly constructing information with Seyyah

\begin{tabular}{lllc}
\hline & \multicolumn{1}{c}{ Codes } & Participants & $(f)$ \\
\hline \multirow{2}{*}{1} & $\begin{array}{l}\text { It provides the structuring of the information by synthesizing the } \\
\text { new information with the prior knowledge. }\end{array}$ & c4, c7, c8, c10 \\
\hline 2 & It provides versatile thinking while structuring the information. & c1, c3, c5, c9 & 4 \\
\hline 3 & Information is structured jointly. & c6 & 1 \\
\hline 4 & $\begin{array}{l}\text { In the process of structuring the information, the system runs } \\
\text { slowly. }\end{array}$ & c2 & 1 \\
\hline Total & & 10 \\
\hline
\end{tabular}

Some of the statements of the Social Studies teacher candidates regarding the process of structuring information with Seyyah are as follows:

Student 4 (It provides the structuring of information by synthesizing new information with prior knowledge):

"In this process, we see that the person can access new information by synthesizing what he obtained as a result of his researches with the information he already kne also in researches. Also, in researches, when we do not match our own experience and knowledge, we will see that the information is not fully provided and that the student is structuring his own knowledge in this process and that we have a more efficient process."

Some of the candidates $(n=4,40 \%)$ stated that they synthesized new information with the existing information on Seyyah and thus constructed the information jointly. This may mean that the use of Seyyah provides a chance to develop higherorder thinking skills. 
Student 1 (It provides versatile thinking while structuring the information):

"It is an important application for comparing what is known with what is unknown, more importantly for interpreting what is known. Seyyah takes the person away from the knowledge and improves the power of interpretation and versatile thinking."

Some of the candidates ( $\mathrm{n}=4,40 \%$ ) stated that it provides an opportunity to develop versatile thinking while constructing information in Seyyah. This may mean that the use of Seyyah provides a chance to develop versatile thinking skills.

Student 6 (Information is structured jointly):

"The sentences that I quoted in two sentences turned into long sentences over time. And by reading my friends' comments, I identified them with my own information and made more logical comments and transferred them to Seyyah. I shared my own information by getting different information."

Candidate stated that the information was jointly constructed on Seyyah. This may mean that Seyyah allows information to be jointly constructed.

Teacher candidates' opinions about presentation of Turkish culture in a different form through using Seyyah. When Table 10 is analyzed, it is seen that Social Studies teacher candidates express their views on presentation of Turkish culture in a different form through using Seyyah under four (4) different codes.

Table 10

Teacher Candidates' Opinions About Presentation of Turkish Culture in a Different Form Through Using Seyyah.

\begin{tabular}{lllc}
\hline \multicolumn{1}{c}{ Codes } & Participants & $(f)$ \\
\hline 1 & It allowed to perceive culture. & $\mathrm{c1,c8,c9,c10}$ & 4 \\
\hline 2 & Different gains were achieved. & $\mathrm{c3,}$ c5, c6 & 3 \\
\hline 3 & The continuity and change of culture over time was perceived. & $\mathrm{c4}, \mathrm{c7}$ & 2 \\
\hline 4 & It associated history with geography. & $\mathrm{c2}$ & 1 \\
\hline Total & & 10 \\
\hline
\end{tabular}

Some of the statements of the Social Studies teacher candidates regarding presentation of Turkish culture in a different form with Seyyah are as follows:

Student 8 (It allowed to perceive culture):

"By considering the information we obtained as a result of our work and the characteristics of our culture, thanks to the information we have obtained, it will enable our past history to emerge widely. And it will make us realize once again how deep and deep-rooted culture we have."

Some of the candidates ( $\mathrm{n}=4,40 \%)$ stated that cultural characteristics can be perceived by using Seyyah. This may mean that Seyyah plays a role in promoting culture.

Student 6 (Different gains were achieved.):

"Our culture with Seyyah was of course very different because we interpreted the first map found with the traveler, it was like looking for a needle in a haystack. When just looking, there were lines, circle shapes. However, when it got inside, everything was very, very different. Every line had a meaning and dozens of things could come out of that meaning. I learned this with the 
traveler. "

Some of the candidates $(n=3,30 \%)$ stated that different gains were achieved by using Seyyah. This may mean that Seyyah is a multidimensional learning environment.

Student 4 (The continuity and change of culture over time was perceived):

"The idea that our culture, which is dominated by very structured, very different and quite wide places, is actually associated with many places and areas was presented on this different platform. This made us even more attractive, we have seen that places and dominations have changed in the process and that our culture continues with different forms and names. And while we only know the parts of the whole, it was very useful to examine it as a whole."

Some of the candidates $(n=2,20 \%)$ stated that the perception of cultural continuity still occurs through using Seyyah. This may mean that Seyyah plays a role in promoting culture differently.

Teacher candidates' determinations about using Seyyah. When Table 11 is analyzed, it is seen that Social Studies teacher candidates expressed their opinions about using Seyyah under six (6) different codes.

Table 11

Teacher candidates' determinations about using Seyyah

\begin{tabular}{|c|c|c|c|}
\hline Codes & Descriptions & Participants & $(f)$ \\
\hline 1 It provides synthesis. & It gives different skills. & $\mathrm{c} 1, \mathrm{c5}, \mathrm{c} 6, \mathrm{c} 8, \mathrm{c} 10$ & 5 \\
\hline 2 It provides analysis. & $\begin{array}{l}\text { It allows you to think deeply and } \\
\text { analyze the information. }\end{array}$ & c4 & 1 \\
\hline $\begin{array}{ll}3 & \text { It improves } \\
\text { interpretation power. }\end{array}$ & It provides high level skills. & c9 & 1 \\
\hline 4 It provides foresight. & $\begin{array}{l}\text { It establishes the relationship between } \\
\text { past, present and future. }\end{array}$ & c7 & 1 \\
\hline 5 It gives pride. & It contributes to the world of science. & c3 & 1 \\
\hline 6 It attracts attention. & Mobile interface is required. & $\mathrm{c} 2$ & 1 \\
\hline \multicolumn{3}{|l|}{ Total } & 10 \\
\hline
\end{tabular}

Some of the determinations of the Social Studies teacher candidates about using Seyyah are as follows:

Student 5 (Enables synthesis - Enables discovery):

"As you collect information, do research and find new things, it creates a sense of research curiosity and allows us to combine them with the information we have in ourselves. It also improves our imagination while demonstrating our ability to comment."

Some of the candidates $(n=4,40 \%)$ stated that using Seyyah provides an opportunity to develop synthesis skills. This may mean that Seyyah supports the development of high-level skills.

Student 4 (Enables analysis - urges to think):

"In this study, we saw that different places and dominations are related to both geography and the formations around it, we also listened that many existing places are related to random stories. We found that there are also related places. During our work, we were able to make some assumptions about the cultural, economic and climatic features of the places, we could relate our 
geographical information as a whole, and with a constructivist approach, we made our previous knowledge more meaningful with our new knowledge."

The candidate stated that using Seyyah provides an opportunity to develop analysis skills. This finding can be interpreted that using Seyyah developed highlevel skills.

Student 9 (Improves interpretation power - Provides high-level skills):

"It provides the development of the individual's critical skills. It improves the power of interpretation based on the figures shown. "

The candidate stated that using Seyyah developed their interpretation skills. This may mean that using Seyyah plays a role in developing high-level skills.

Student 7 (Provides foresight-Establishes the relationship between past, present and future.):

"Thanks to Seyyah, it enabled me to get new information about the countries and places I heard for the first time, and it allowed me to see the past history of these countries closely. Thus, it enabled me to foresee about the past, present and future."

The candidate stated that using Seyyah supports the abiity to make predictions. This may mean that using Seyyah allows candidates to establish foresight and relationship.

Student 3 (It is proud - Contributes to the world of science):

"It was a source of pride for me that Turks engaged in scientific research in a world where even Europe was in a dark age at that time and there is a map that has kept its secret to this time. I am fortunate to be a part of such a study and I am proud of my history, this work will provide important and good contributions to Turkish history."

The candidate stated they were proud of their history for participating in this study. This finding may be related to using Seyyah as a contribution to science and preservation of cultural history.

Student 2 (It attracts attention- Mobile interface is required):

"I liked Seyyah very much. I was very interested. I was not aware of such a map until this application, but I hope it works better on mobile. It might be more interesting if it works better on mobile."

The candidate stated that they loved using Seyyah very much and with Seyyah, they became more aware about the world map drawn by Kashgarli Mahmud. Student 2 also mentioned that the mobile interface of Seyyah should be improved. These findings may mean that using Seyyah has made a cultural element popular but must have different interfaces.

\section{Result and Discussion}

In this study, Social Studies teacher candidates had the opportunity to apply two basic skills from in the Social Studies curriculum through using a GIS application called Seyyah. Thus, the information obtained by using evidence from the world map 
drawn by Kashgar Mahmud has been transformed by jointly constructing political information. Such a process resulted in a different presentation of an important concrete Turkish cultural element, and the process was evaluated by Social Science teacher candidates.

The results for determining how Social Studies teacher candidates jointly constructed political information using existing knowledge and evidence from the the world map drawn by Kashgar Mahmud in Divan-ı Lugati't-Turk can be summarized as follows:

Cities are expressed under four headings according to their geographical, ethnicity, power and religious features. Political information was created according to the geographical features of the cities, their geopolitical features and their climate. Ethnicity characteristics were explained by cultural ethnic groups. Cities were expressed in terms of technology, social life, social event, state and border under the power category. In terms of religion, the cities are discussed in terms of heavenly religions, monotheistic religions and Zoroastrianism. Therefore, political information about cities has been examined in different dimensions according to geography, ethnicity, power and religion. However, cities were understood to exist mostly within the scope of power related political information.

Countries have been evaluated under four headings according to their geographical, ethnicity, power and religious features. The geographical characteristics of the countries were expressed according to their location and climate. Ethnicity characteristics were evaluated for cultural and ethnic groups. Countries were understood in terms of their economy, social problems, independence, state, social structure and assimilation in terms in power dimensions. Countries were explained religiously as Judaism, the Lost, the Christians, and those who did not accept Islam. Such explanations show that political information about countries are in different dimensions according to geography, ethnicity, power and religion. However, countries were most commonly structured in terms of ethnicity.

Physical elements are examined under four headings according to their geographical, ethnicity, power and religious features. The physical elements or geographical features were interpreted according to their location, geopolitical features and natural features. Ethnicity features in the context of cultural, power dimension in politics context and religious aspect only in the context of disbelief were evaluated. These show that political information about physical elements is different but small in size depending on geography, ethnicity, power and religion. It is seen that physical elements are mostly structured jointly according to geographical features.

The realms are explained under four headings according to their geographical, ethnicity, power and religious features. The geographical features of the realms were evaluated according to their location, climate and physical characteristics. Ethnicity characteristics have been explained with various ethnic groups; power characteristics have been explained with war, state, domination, economy, sovereignty, politics, migration, social problem, change over time. Realms were only associated with Islam in terms of religion. These show that the political information 
about the lands is in different sizes in terms of geography, ethnicity, power and religion. However, the lands were most commonly structured according to their power characteristics.

Other geographical indications are expressed under three headings according to their geographical, power and religious features. The geographical features of other geographical signs were discussed according to their location, climate and physical condition. There are no ethnic characteristics. Other geographical indications were explained as celestial, celestial and non-celestial religions in terms of religion and as national sovereignty, social problem and politics in terms of power. These show that the political information about other geographical signs are in different dimensions according to geography, power and religion. However, in other geographical signs, the information was jointly structured by considering the most geographical features.

The geographical features of the nations were analyzed according to their geographical and geopolitical characteristics, ethnicity according to the ethnic group types, and the power characteristics were analyzed according to the state, migration and politics. These show that political information about nations was evaluated according to geography, ethnicity and power. The religious characteristics of nations were not mentioned. For nations, political knowledge was most commonly structured in terms of power.

Since there is no similar study in the relevant scientific literature, the discussion of the research was conducted through studies in which evidence utilization and political literacy skills were evaluated, and the relationship between knowledge structuring and culture - technology was handled.

The results for determining Social Studies teacher candidates' opinions about Seyyah can be summarized as follows:

The results obtained from the opinions about the evidence-based learning with Seyyah show that Seyyah enables the comparison of information with evidence to occur. The use of Seyyah also helps Social Science teacher candidates to develop higher-order thinking skills, convey objective information and acquire new information. Such results are supported by Acar (2013), Akbaba (2005), Alabaş (2007), Ata (2011), Balkaya (2002), Bilgiç (2018), Bozkurt (2018), Çıdaçı (2015), Çiftarslan (2019), Doğan (2007), Doğan (2008), Doğan and Dinç (2007), Dönmez and Altıkulaç (2014), Işıı (2008), Sağlam and Bilgiç (2018), Şekerci and Kabapınar (2019), Şengül Bircan and Safran (2013).

The results obtained from the Social Science teacher candidate opinions about the development of political literacy skills through using Seyyah show that Seyyah can be associated with the development of political literacy skills when using a form of evidence (such as the world map) combined with existing knowledge. It was reported that the use of Seyyah develops different skills, and leads the Social Science teacher candidates to research further because their curiosity was aroused. However, one of the findings is that the use of Seyyah does not support the development of political literacy skills. While these results show that political literacy skills can be used on Seyyah, it is similar to the results of studies evaluating political knowledge and literacy made by Akhan (2011), Bektaş and Zabun (2019), 
Kara and Tangülü (2017), Kaya (2013), Kuş and Tarhan (2016), Tarhan (2015), Yıldırım, Öntaş and Egüz (2018).

The results obtained from the opinions about the process of organizing and interpreting the information in Seyyah concluded that the use of Seyyah's supported an information structuring process, and synthesis of preliminary and existing information. Furthermore, the use of Seyyah made thinking more versatile about the way information could be structured. In addition, a result was obtained that the system was running slowly. These results explain that information in Seyyah can be jointly constructed. The structure of information in Seyyah has been the subject of studies of Sert and Balaman (2015) and Avcı Yücel (2013), and thus positive results have been obtained in support of the current research findings.

The results obtained about the use of Seyyah enabling the presentation of Turkish culture in a different form leads the conclusion that Seyyah can present cultural elements in different forms and the cultural continuity and change can be perceived over time although it provides different gains and relates to the historical geography. Such a result supports Akşit (2011) 's view of shaping the culture through the use of technology. Also results from the current study support the claim that different achievements are gained by presenting a cultural element in a different form in the Social Studies curriculum

"By understanding the basic elements and processes that make up the Turkish culture and history, he acknowledges that the cultural heritage that enables the formation of national consciousness should be preserved and developed." and "Identifying the similarities and differences between people, objects, events and phenomena, perceiving change and continuity by questioning historical evidence of different periods and places". (Ministry of National Education [MoNE], 2018, p. 8)

In addition, these results show that cultural elements can be transformed into geographical data by adding a different dimension to GIS.

The results obtained from the general opinions about Seyyah show that Seyyah enables the Social Science teacher candidates to synthesize, analyze, interpret and predict information in the interpretation and organization process. At the same time, using Seyyah attracts Social Science teacher candidates and makes them proud of their work. Such results explain that Social Studies teacher candidates were positively influenced by the use of Seyyah and were also able to develop their highlevel skills, which is supported by the results of a study conducted by İneç (2012).

In this study, the world map drawn by Kashgar Mahmud is a culturally important Turkish resource and the use of Seyyah has enabled the map to become a dynamic feature on the internet.

Thanks to evidence-based learning processes and the development of political literacy skills, Social Studies teacher candidates have had the opportunity to perceive and build their understanding about the period of time in question.

This is the first time that a cultural element has been implemented into Seyyah and in which Social Science teacher candidates have jointly constructed information using their different skills. 
Evidence-based learning with Seyyah has found a new application opportunity in accordance with the constructivist approach. An interactive environment where information is jointly constructed has been created by also developing political literacy skills.

\section{Suggestions}

In the Social Studies Curriculum, new scientific studies can be carried out by utilizing technology integration to support and develop the basic skills necessary to be acquired by students. As an example, our concrete cultural elements, such as a hand-drawn world map, can be integrated into similar studies and presented to students in a different form, such as through GIS applications.

Thus, it can be ensured that the basic skills foreseen in the curriculum are evaluated from different perspectives,

New technology-based applications can be planned for future use in Social Science courses to introduce, grasp and popularize cultural elements,

New technology-based teaching applications can be implemented in Social Science courses where students can collectively create information,

Communication products, which are one of the impact channels of globalization, can be used to make national cultural elements popular, as shown in the current study,

The basic skills, competencies, achievements and values that make up the curriculum can be comprehensively evaluated in many ways by involving students in their learning and supporting them with the use of new technologies.

\section{References}

Acar, H. (2013). Research on using evidence skills in secondary school geography books and its effect to students' academic achievement. (Unpublished master thesis). Marmara University Institute of Educational Sciences, İstanbul.

Altun, S. A. \& Memişoğlu, S. P. (2008). The opinions of teachers, administrators and supervisors regarding performance assessment. Educational Administration: Theory and Practice. (53). 7-24.

Akbaba, B. (2005). Photograph usage in history education. Ahi Evran University Journal of Education Faculty. 6(1). 185-197.

Akhan, O. (2011). Determining the tendencies of Social Studies pre-service teachers towards political science. (Unpublished master thesis). Gazi University Institute of Educational Sciences, Ankara.

Akşit, O. (2011). Tekno-bilim ve tekno-kültür. Illetişim Günleri - 6. İzmir, Turkey.

Alabaş, R. (2007). Evidence based learning model in the 6st grade primary school, Social Studies lesson: An action research. (Unpublished master thesis). Marmara University Institute of Educational Sciences, İstanbul.

Aslan, C. (1999). Kaşgarlı Mahmut (XI. yüzyıl). Turkish Librarianship. 13(4). 458-462.

Ata, B. (2011). A good example of Social Studies education: the American memory project from the library of congress. Turkish Librarianship. 25(2). 261-270. 
Ineç, Z. F.; Akpinar, E. (2020). Digitizing and Interpreting the World Map Drawn by Kashgarli....

Atalay, B. (2018). Kaşgarlı Mahmud Divanü Lügat-it Türk Çeviri. Ankara: Turkish Language Association.

Avcı Yücel, Ü. (2013). Interaction and participation in knowledge building processes within the online collaborative learning environments. (Unpublished master thesis). Hacettepe University Institute of Science, Ankara.

Balkaya, A. (2002). Effectiveness of historical evidence in teaching history subjects on social studies course in primary school. (Unpublished master thesis). Marmara University Institute of Educational Sciences, İstanbul.

Bektaş, Ö. \& Zabun, E. (2019). Social Studies teachers' political skills. The Journal of International Social Research. 12(63). 789-796.

Bilgiç, S. (2018). An action research related to a evidence based learning in 4th grade social science course. (Unpublished master thesis). Sakarya University Institute of Educational Sciences, Sakarya.

Bozkurt, F. (2018). Evidence based learning applications in Social Studies education. Mediterranean Journal of Educational Research. 12(24), 334-353.

Branch, R. M. (2016). Instructional design: the ADDIE approach. (I. Varank, Trans.). Konya: Eğitim. (Original work printing date 2009).

Büyüköztürk, Ş., Kılıç Çakmak, E., Akgün, Ö. E., Karadeniz, Ş. \& Demirel, F. (2013). Bilimsel araştırma yöntemleri. Ankara: Pegem Akademi.

Canpolat, M. (2008). Kaşgarlı Mahmud: ilk Türk etimoloğu. Kaşgarlı Mahmud Kitabı (1.bs.) into (pp.85-91). Ankara: Ministry of Culture and Tourism.

Çıdaçı, T. (2015). The use of main resources obtained in the teaching of history Social Studies topics. (7th grade samples) (evidence-based learning). (Unpublished master thesis). Muğla Sıtkı Koçman University Graduate School of Educational Sciences, Muğla.

Çiftarslan, N. (2019). Teaching T.C. history of revolution and Kemalism at 8th grade level through evidence-based learning approach: A phenomenological study. (Unpublished master thesis). Marmara University Institute of Educational Sciences, İstanbul.

Dilek, D. (2007). Tarih derslerinde öğrenme ve düşünce gelişimi (3.bs). Ankara: Nobel.

Doğan, Y. (2007). The use of written historical evidences in Social Studies teaching. (unpublished doctoral dissertation). Gazi University Institute of Educational Sciences, Ankara.

Doğan, Y. (2008). The effect to student's academic success use of historical written evidence in Social Studies teaching. TSA. 12(2). 171-186.

Doğan, Y. (2009). Sosyal bilgiler program ve ders kitaplarında birinci elden kaynak ve kanıt kullanımı: ABD, İngiltere ve Türkiye karşılaştırması. In Turan, R., Sünbül, A. M. \& Akdağ, H. Sosyal bilgiler öğretiminde yeni yaklaşımlar - 1. (pp.85-128). Ankara: Pegem Akademi.

Doğan, Y. \& Dinç, E. (2007). The use of historical primary sources through the internet in Social Studies and history classes: some examples from the USA and the UK. TSA. 11(2).195-220.

Dönmez, C. \& Altıkulaç, A. (2014). Social Studies teacher candidates' opinions regarding using historical sources in teaching of T.R. history of the revolution and Kemalism course in secondary school. Kastamonu Education Journal. 22(3). 923-942. 
Eraslan, K. (2008). Kaşgarlı Mahmud: ilk Türk sözlükçüsü. Kaşgarlı Mahmud Kitabı (1.bs.) into (pp.83-84). Ankara: Ministry of Culture and Tourism.

Ercilasun, A. B. (2008). Kaşgarlı Mahmud: ilk Türk gramercisi. Kaşgarlı Mahmud Kitabı (1.bs.) into (pp.93-105). Ankara: Ministry of Culture and Tourism.

Ercilasun, A. B. \& Akkoyunlu, Z. (2018). Divanu Lugati't Türk. (3. bs.). Ankara: Turkish Language Association.

Görmez, E. (2018). A Study on the adequacy of the updated Social Studies program in terms of political literacy skill. Anemon Journal of Social Sciences of Mus Alparslan University. 6(STEMES'18), 109-114.

Gül, B. (2008). Bir sözlüğün hikayesi. Kaşgarlı Mahmud kitabı (1.bs.) into (pp.137-148). Ankara: Ministry of Culture and Tourism.

İneç, Z. F. (2012). Web based geographical information system application in Social Studies education. (Unpublished master thesis). Erzincan University Institute of Social Sciences, Erzincan.

İneç, Z. F. \& Akpınar, E. (2012). A web based geographical information system application: Seyyah. Erzincan University Journal of Education Faculty. 14(2). 111-130.

Işık, H. (2008). Evidence based learning model in primary school, Social Studies lesson: An action research. (Unpublished master thesis). Marmara University Institute of Educational Sciences, İstanbul.

Kabapınar, Y. (2014). Kuramdan uygulamaya sosyal bilgiler öğretimi. Ankara: Pegem Akademi.

Kabapınar, Y. (2019). Kanıt temelli öğrenme; tanım, kapsam, yaklaşımlar. Kimlik belirleyen derslerde kanıt temelli ögrrenme (1.bs.) into (pp.29-54). Ankara: Pegem Akademi.

Kara, H. \& Tangülü, Z. (2017). A case study on legal and political literacy at the Social Studies curriculum. Research and Experience Journal. 2(1). 1-28.

Kaya, B. (2013). An analysis of the relationship between citizenship perceptions and political interests and participation of pre-service Social Studies teachers. (Unpublished master thesis). Marmara University Institute of Educational Sciences, İstanbul.

Kuş, Z. (2013). Politik okuryazarlık ve aktif vatandaşlık. Sosyal bilgiler için çoklu okuryazarlıklar. into (pp.208-229). Ankara: Pegem Akademi.

Kuş, Z. \& Tarhan, Ö. (2016). Political education in Social Studies classrooms: a perspective from Turkey. Journal of Theory and Practice in Education. 12(3). 464-483.

Miles, M. B. \& Huberman, A. M. (1994). Qualitative data analysis: an expanded sourcebook. (2. bs.). California: SAGE.

Ministry of Environment and Forestry (MEF), (2008). Coğrafi bilgi sistemleri çalışma esas ve usulleri hakkında tamim. Retrieved from https://www.ogm.gov.tr/ekutuphane /Tamimler/Coğrafi\%20Bilgi\%20Sistemleri\%20Çalışma\%20Esas\%20ve\%20Usuller i\%20Hakkında\%20Tamim.pdf.

Ministry of National Education [MoNE], (2018). Sosyal bilgiler dersi ögretim programı. Retrieved from: http://mufredat.meb.gov.tr/Dosyalar/201812103847686SOSYAL\%20B\%C4\%B0LG\%C4\%B0LER\%20\%C3\%96\%C4\%9ERET\%C4\%B0M\%20 PROGRAMI\%20.pdf.

Patton, M. Q. (1987). How to use qualitative methods in evaluation. Newbury Park, California: SAGE. 
Sağlam, H. İ., Bilgiç, S. (2018). Investigation of the effect of evidence-based learning in primary school 4th grade Social Studies lesson. Sakarya Univ. Journal of Education. $8(2) \cdot 60-71$.

Sarıcaoğlu, F. (2008). Kaşgarlı Mahmud: ilk Türk haritacısı. Kaşgarlı Mahmud kitabı (1.bs.) into (pp.121-132). Ankara: Ministry of Culture and Tourism.

Sert, O., Balaman, U. (2015). A conversation analytic investigation into co-construction of knowledge in online task-oriented interaction. Mersin University Journal of Linguistics and Literature, MEUDED. 12(2). 45-72.

Şekerci, H., \& Kabapınar, Y. (2019). Using evidence-based teaching activities integrated with the storyline approach in the Social Studies courses. H. U. Journal of Education. 34(3). 659-684.

Şengül Bircan, T. \& Safran, M. (2013). The usage and the importance of maps in teaching history. Ahi Evran University Journal of Education Faculty (KEFAD). 14(2). 461-476.

Tarhan, Ö. (2015). Social Studies teacher candidates' views on political literacy. The Journal of Academic Social Science. 3(9). 649-669.

University of Birmingham (UoB), (2002). Political Literacy within ITT Citizenship Education. Retrieved from http://www.citized.info/pdf/conferences/pilot/NovWorkshop.pdf.

Yaylagül, Ö. (2009). Divanu Lugat'it-Turk in terms of semiology. The Journal of International Social Research. 2(6). 690-698.

Yıldırım, A. \& Şimşek, H. (2013). Sosyal bilimlerde nitel araştırma yöntemleri. Ankara: Seçkin.

Yıldırım, D. (2008). Kaşgarlı Mahmud: ilk Türk sözlü kültür bilimcisi (folklorist). Kaşgarlı Mahmud Kitabı (1.bs.) into (pp.107-119). Ankara: Ministry of Culture and Tourism.

Yıldırım, E., Öntaş, T. \& Egüz, Ş. (2018). An investigation into the relationship between citizenship perceptions, political contributions and political interests of primary and Social Studies teachers. Karaelmas Journal of Educational Sciences. 6, 163-175.

\section{Biographical Statements}

Zekeriya Fatih İNEÇ is an Assistant Professor at the Faculty of Education in Erzincan Binali Yıldırım University, where he is Pre-School Education Department. His research interest includes Social Studies education, instructional technologies and instructional materials design.

Erdal AKPINAR is a Professor Doctor at the Department of Social Studies Education at the Erzincan Binali Yıldırım University. He teaches human geography, scientific research methods and Social Studies education. 